\title{
The Mediation Effect of Restaurant Image on the Relationship between Service \& Food Quality and Customer Satisfaction.
}

\author{
Zeferina Celeste da Costa Oliveira, Manuel Vong, Estanislau de Sousa Saldanha \\ Graduate School-Master of Business Administration (MBA) Program \\ Dili Institute of Technology (DIT), Timor-Leste \\ Email:wostyia@gmail.com, estanislausaldanha@yahoo.com, manuelvong@gmail.com
}

\begin{abstract}
The purpose of this study is to examine the mediation effect of restaurant image on the relationship between service qualities, food quality and customer satisfaction in restaurant industry. Questionnaire used to collect data, while Smart PLS 3.0 was used to test the hypotheses. The result of this research revealed positive and significant relationships between food quality, service quality, restaurant image and customer satisfaction. The other hand, there is no mediation effect of restaurant image in relationship among food quality, service quality and customer satisfaction. This research provides data on the level of consumer satisfaction with food quality, the quality of service in Timor-Leste. The Government may use this information in developing training centres to provide training to staff to improve their skills and knowledge about food services.
\end{abstract}

Keywords: Food quality, service quality, restaurant image and customer satisfaction, Timor-Leste.

\section{Introduction}

Customer satisfaction is important factor for goods marketing. A product is success if customers satisfy with it. Consumer satisfaction is the results from people's comparison between their expectations and the perceived service obtained from a company (Nawi et al., 2019; Kotler, 2014). Customer satisfaction is a result of consumer service needs (Barnes, 2003: 64). Kotler (2003) indicates a company must maintain its income, and this requires customer satisfaction. Firescu (2015), mentioned that consumer satisfaction for an industry is very important because only through consumers can provide income for the industry, when there are no consumers there is no income, therefore an industry needs to pay attention to staff to provide satisfaction to consumers (Ryu, Lee \& Kim, 2012).

Timor-Leste is experiencing growth in the hotel sector, with more than 200 currently trading (IADE 2019). However, many do not yet provide good quality food and service. AIFAESA closed many hotels in Dili, because they do not have good quality food, and consumers are not satisfied with their services. This situation became more severe during the Covid-19 Pandemic since hotels had few customers.

Satisfaction is an evaluation by consumers of the goods and services they use (Ali et al., 2019; Khattab, 2018). Abdullaeva (2020) mentioned that satisfaction is a person's evaluation of the value of a product that is received by consumers. Measurement of customer satisfaction is difficult and everyone's evaluation is different, as there are many factors determining service quality as a determinant of customer satisfaction (Zameer et al., 2015).

\section{Theoretical Framework, Conceptual Model and Hypothesis}

\subsection{Theoretical Frameworks and Conceptual Model}

\subsubsection{Restaurant Image}

Image is the most important component of a marketing strategy and can be used by managers to increase customer satisfaction (Ryu et al., 2012). Image is a subjective interpretation of reality by the consumer (Iordanova and Stylidis, 2019). Restaurant image has four dimensions namely are food quality, service quality, physical environment and fair price (Meesala \& Paul, 2018; Consumers want a good interior design in a good seat conditions, good music, good lights according to conditions, all of this is prepared by the manager in accordance with consumer desires and market demands (Shields, 2006).

\subsubsection{Service Quality}

Service quality is the most important part for a business to make consumers feel comfortable and happy in using products from the hotel industry (Kotler, 2000; Ruslan, 2006). There are several activities that are given by one party to another, hence what is called intengible activity. The results and measurements of service quality depend on the type of service process, time, situation, needs and other factors (Sharabi \& Davidow, 2010). According to Gummesson, (1998) service is an activity that we see every day and contribute to its value. On the other hand, service is very important as a priority in the service sector. From some of these opinions, there are differences, namely service as an 
Vol.2, Issue.2, pp.10-20, 2020

Available online at: https://tljbm.org/jurnal/index.php/tljbm

activity, value and ownership which businessmen must instil in an organization. Service quality as an important criterion to grow, promote customer satisfaction. Quality service with good results will increase customer satisfaction and loyalty (Meesala \& Paul, 2018; Hapsari et al., 2017).

\subsubsection{Food Quality}

Food quality can be seen from several aspects, namely: food safety, nutrition contributes to health, presentation and easy to process (Vijver, 2007). There are differences of opinion about quality because it depends on the context. According to Davis cited by Yamit (2010) quality as a dynamic condition that has a relationship with production, individual work and environmental services to consumer expectations. According to Carranza et al., (2018) mentioned that food quality is the most important element in a compared to the architecture in a restaurant.

Quality does not only come from goods or services, but also from food production. Consumers who want to buy food generally want to buy quality food. According to Kotler \& Amstrong (1998), production quality as a characteristic of production or service that has the ability to comply with consumer satisfaction..

\subsubsection{Consumer Satisfaction}

According to Pooya et al., (2020), Consumer satisfaction as an evaluation of product purchases compared to existing or desired feelings. Mannan, et al., (2019), and Kotler \& Keller, (2012), satisfaction comes from the feeling of people who are happy with the product purchased. If the service is not carried out according to their wishes, consumers will not be satisfied and if it is according to their wishes, they will be happy and give deeper appreciation. Value seen from many factors, especially seen from consumer loyalty to product quality. Consumers always give a good perception of the product and quality which they feel positive for them. Souki et al., (2019); Kotler, (2014:150) mentioned that Satisfaction as part of feeling to compare the work that is being awaited

\subsubsection{Food Quality and Consumer Satisfaction}

Food quality is a principal attribute that affects consumer satisfaction. It is generally agreed that food quality is a basic element of the consumer experience in a. When the food is good, it will provide benefits for both parties, namely s and consumers Truong et al., (2004). Alli (2004), Qin et al., (2009) mentioned that the quality of food and drink has 4 dimensions, namely: 1. Freshness, 2. Presentation, 3. Wellcooked 4 . Variety of food.

\subsubsection{Restaurant Image and Consumer Satisfaction}

Ryu et al. (2012) mentioned that image is a component of marketing strategy for managers to influence consumers, through the value and satisfaction felt by consumers. The place must be strategic and easily accessible to consumers and the architect of the must be elegant (Zameer et al., 2015). To ensure customer satisfaction, it is necessary to have a strategic place that is easy and fast to access by consumers. According to Ryu et al. (2008; 460) defines that the image is a general evaluation of consumers about the attributes that exist in the restaurant.

\subsubsection{Service Quality, Restaurant Image and Consumer Satisfaction}

Service quality is a determinant factor for companies to earn income. According to Meesala \& Paul (2018), the company must create a standard for its staff in order to guarantee the quality of service in the company. Good service quality is very important for the industry to ensure customer satisfaction. Kotler (2004:42) stated that consumer satisfaction comes from feelings of pleasure and displeasure from individuals when comparing the products used. Industry success comes from good working capacity for consumers so that consumers feel satisfied and provide a positive perception for the image. Image as a perception in the minds of consumers that before imagining the cleanliness of the strategic conditions and attractive architectural designs.

\subsubsection{Food Quality, Restaurant Image and Consumer Satisfaction}

Food quality will come from food preparation from the person who provides it and must know about the menu and ingredient used for cooking in order to get quality food (Karen Bruns et, al 2002; Sadilek, 2019). Food is a concept with many purposes, the motive of choice as an evaluation of the consumer. Some researchers say that the quality of food is seen by menu variations, types of food and prices, thus food is the principal product. According to Richardson et al., (2019) and Knight \& Kotschever, (2000) mentioned that food quality is a level that is consistent with the quality of the menu to be achieved and builds a product standard to control food quality and how to achieve goals.

\subsubsection{Conceptual Model}

This study was conducted to examine the job relationship of staff regarding service and food preparation. This research model is built from study of Kotler and Keller (2009:164) on customer satisfaction and service quality, while Erkmen \& Hancer (2019) on restaurant image, and Kotler \& Armstrong (2012) on food quality. The indicators of this variable are adopted from Ryu et al. (2012). From here, the authors build a research model as in Figure 2.13 below: 


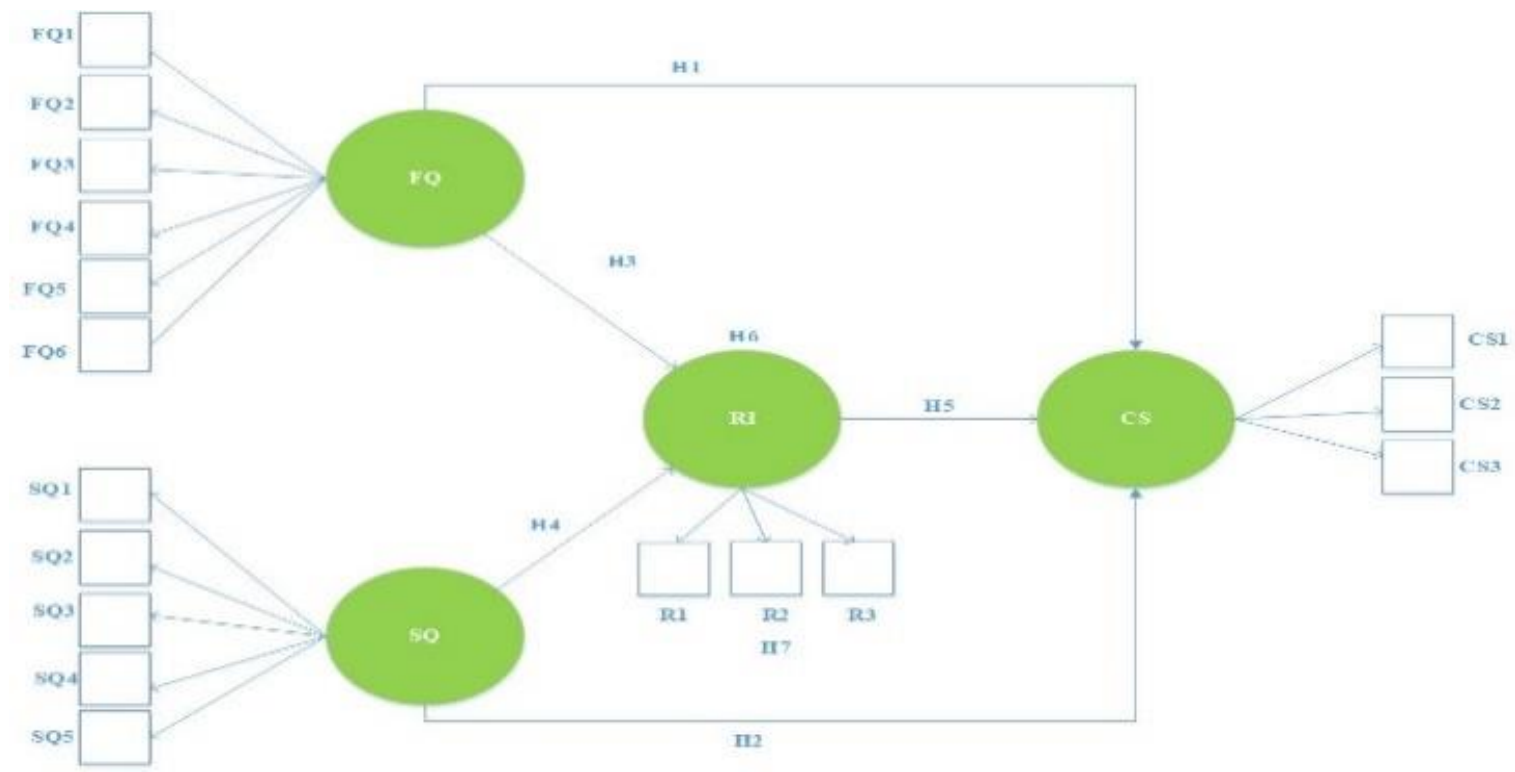

Figure 1. Conceptual model $(\mathrm{FQ}=$ food quality, $\mathrm{SQ}=$ quality service, $\mathrm{RI}=$ Restaurant Image $\mathrm{CS}=$ customer satisfaction)

\subsection{Hypothesis}

\subsubsection{Food Quality and Costumenr Satisfaction}

Food quality is very important for consumers' view of food which must be of high quality and can be seen from the food color, presentation, portion and price (Margaretha and Edwin, 2012). The hypothesis is formulated as follow:

$\mathrm{H}_{1}$ : Food quality has a positive and significant effect on consumer satisfaction

\subsubsection{Service Quality and Costumer Satisfaction}

Service quality is a dynamic condition that affects products, services, humanity, processes and the environment in accordance with consumer expectations. (Tjiptono, 2001). On the other hand, to find out the quality of service by comparing and looking at consumers with the products they use (Tjiptono, 2007). When the product used is not in accordance with their wishes, the clients will not be satisfied and when the product used matches their perception, they will be satisfied with the product.

Service quality has significant relation with consumer satisfacion (Asnawi, Sukoco,\& Fanani 2019; Boonlertvanich, 2019; Chandra et al. 2019; Hapsari, Clemes, and Dean, 2017). Thus the following hypothesis is formulated:

$\mathrm{H}_{2}$ : Service quality has a positive and significant effect on consumer satisfaction

\subsubsection{Food Quality and Restaurant Image}

Food quality is an important attribute that affects a 's image (Soriano, 2007). Seeing the current modern reality in the capital city of Dili, many traders have opened s to serve consumers. The managers think how to prepare quality food in order to influence the 's image (Alli, 2004). Qin et al. (2009) said that the quality of food production has 4 dimensions: freshness, presentation, well cooked and variaety of food. Therefore, the quality of food that is given properly will benefit both parties. The will affect the 's image and the consumers are satisfied as expected and affect the 's image. With that, the hypothesis is formulated as follows:

$\mathrm{H}_{3}$ : Food quality has a positive and significant effect on restaurant image.

\subsubsection{Service Quality and Restaurant Image}

Service quality is the most important factor that affects the value of consumer perceptions, customer satisfaction, and the desire or feeling to return, and to give messages by word of mouth (Ryu et al., 2012). Therefore, the following hypothesis is formulated:

$\mathrm{H}_{4}$ : Service quality has a positive and significant effect on restoran image

\subsubsection{Restaurant Image and Consumer Satisfaction}

Image as an indicator for customer satisfaction. Lai et al., (2009) said that image affects the value of consumer 
perceptions and customer satisfaction. Therefore, the following hypothesis can be formulated:

$\mathrm{H}_{5}$ : Restaurant image has a positive and significat effect on consumer satisfaction

\subsubsection{Food Quality, Restoran Image and Consumer Satisfaction}

Good quality food is an important component of customer satisfaction, and can lead to repeat purcahes (Namkung \& Jang, 2007). Thus, consumers are psychologically under pressure from the workplace or from their families that will have a negative or insignificant impact between image and customer satisfaction (Carr and Pearson, 2002; Cho et al., 2019). Therefore, the following hypothesis can be formulated:

$\mathrm{H}_{6}$ : The restaurant image has no positive and significant effect on the relationship between food quality and consumer satisfaction

\subsubsection{Service Quality, Restoran Image and Consumer Satisfaction}

Service quality as an act aimed at consumers is to determine the difference between images and will have an effect on service that makes consumers feel satisfied. The quality of service is also a variety of services, depending on the person who is preparing to do the service, how to serve and when it will be done. (Kotler \& Armstrong \& saunders 1999). Therefore, the following hypothesis can be formulated:

$\mathrm{H}_{7}$ : The restaurant image has no positive and significant effect on relationship between service quality and consumer satisfaction

\section{Research Method}

\subsection{Population and Sample}

Population as a general area consisting of objects/subjects that can be determined the quantity and characteristics by researchers to conduct research and finally can make conclusions (Sugiyono, 1997:57). Therefore, the researcher wants to generalize the characteristics of consumers through answers about food quality, service quality, and restaurant image on customer satisfaction from five hotels in Dili. Based on data from 2019, it shows that 47,301 consumers came to eat at five hotels.

The sample as part of the population that can be studied by a researcher. Sugiyono $(2014 ; 120)$ say that the sample is part of the population. Use samples to reduce time and costs. Therefore, when selecting samples, you must use a good way to be able to generalize well. To determine the number of samples using the Slovin formula and using a margin of error of $10 \%$ because this research is an exploratory research. With the State Emergency in Timor-Leste it is very difficult to mobilize more respondents.

\subsection{Data Collection Method}

This study uses a questionnaire to collect data. This questionnaire was built through literature revision. This questionnaire was adopted from a variable instrument that has been used by previous researchers in the field of food quality hospitality, service quality, and restaurant image and customer satisfaction. Therefore, the research instrument does not need a validity and reliability test. This questionnaire has a scoring ranging from 1 (strongly disagree) to 5 (strongly agree).

\subsection{Data Analyzing Method}

This research uses descriptive and inferensive quantitative methods. The descriptive method will present data on demographic characteristics and the frequency distribution of respondents about the indicators of this research variable. Units measured on a frequency distribution and a median value. This type of analysis uses the SPSS data analysis instrument. For the inferential quantitative method test using the Smart-PLS 3.0 data analysis instrument. To analyse the data, using the inferential method, this study uses Smart-PLS 3.0 because the data analysis instrument can use a small sample (minimum 30), reflective/formative indicators, multi-variable test, and no need for classical assumption tests. (Hair et al., 2014; Saldanha et al., 2018).

According to Saldanha et al. (2019), when testing using Smart-PLS, it will be carried out through 3 stages, as follows: First, you have to build the model first in Smart PLS 3.0. This model is built based on theoretical and empiric revisions. Second, test the relationship between indicators and variables or constructs (outer model measurement). This will test the reliability and validity of the indicators. To test the reliability using the parameter composite reliability (CR) with Cronbach alpha (CA). A reliable indicator when the $\mathrm{CR}$ value is greater than 0.70 , and CA is greater than 0.70 (Hair et al., 2014; Saldanha et al., 2018). The validity test is divided into two parts, namely: convergent validity (outer loading or indicator loading with average variance extractedAVE) with discriminant validity (Fornell-larcker, Cross load, and Heterotrait-Monotrait). In convergent validity, the indicator is valid when the outer loading $(\mathrm{OL})$ value is greater than 0.7 , and the average variance extracted (AVE) value is greater than 0.5 (Hair et al., 2017; Saldanha et al., 2019). Validity is seen from discriminant validity, a valid indicator when value "root" AVE of an indicator for that indicator is greater than the value of another indicator. (Hair et al., 2014), and value of heterotrait-monotrait (HTMT) smaller than 0.85 (Henseler, Ringle and Sarstedt, 2015). Third, after testing the relationship between indicators and variables (outer model measurement) to see the validity and 


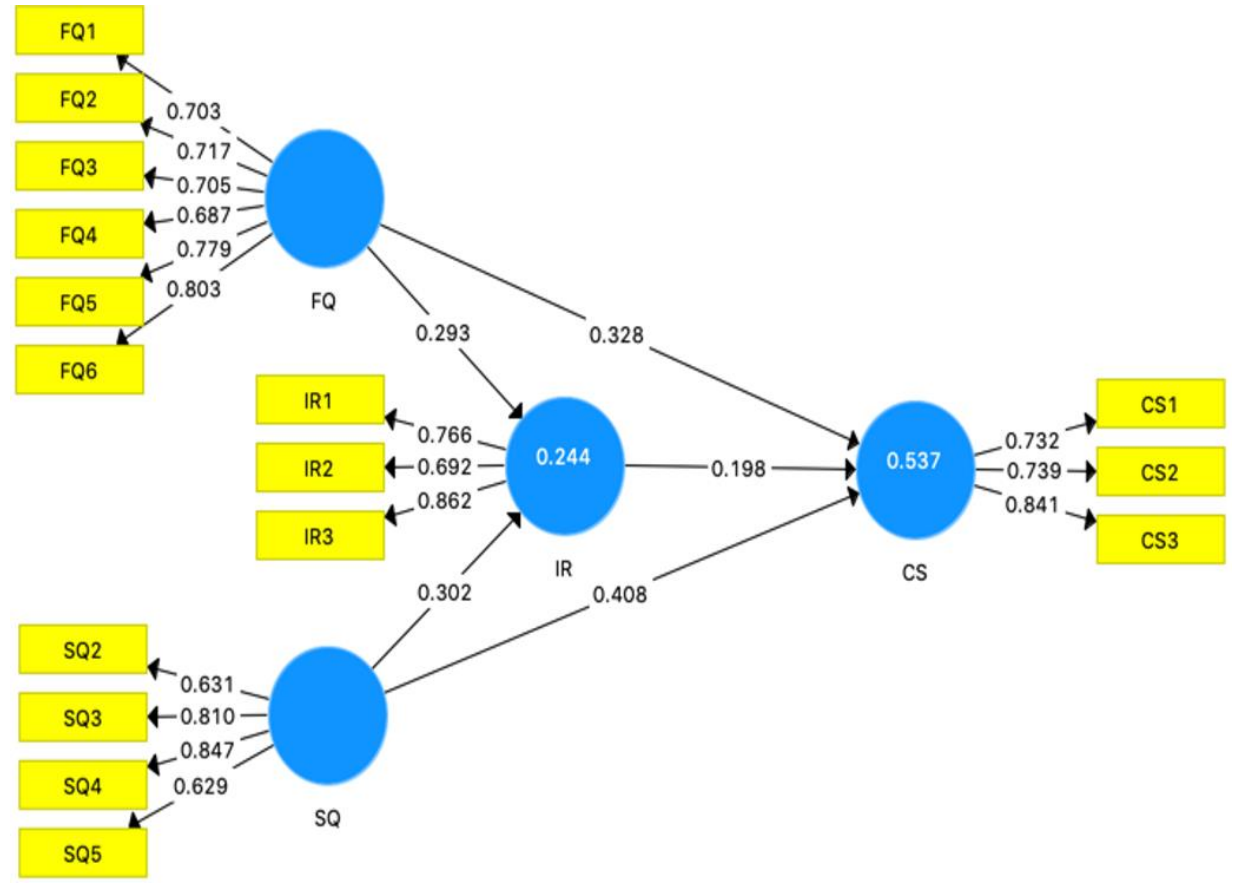

Figure 2 . Outer Loading for Convergent Validity

reliability of each indicator, the next step is to test the significance of the relationship between variables and variables (inner model measurement). It is also used to test hypotheses. In testing the hypothesis, the parameter used is the $\mathrm{T}$ value with the $\mathrm{P}$ value. The relationship between one variable and another variable is significant if the $T$ value is greater than 1.96, and the $\mathrm{P}$ value is smaller than 0.05 (Hair et al., 2017; Saldanha et al., 2019).

\section{Result and Discussion}

\subsection{Reliability}

Reliability test using Cronbach's alpha (CA) parameter with composite reliability (CR). The item/indicator variable is reliable if the CA value is greater than 0.7 and the $C R$ value is greater than 0.7 (Hair et al., 2014; Hair et al., 2017; Saldanha et al., 2019). Look at table I, the CA and CR values are greater than 0.70 , so all items or indicators in this research model are reliable to test the relationship between variables (inner model measurement).

The validity test uses two types, namely convergent validity ho discriminant validity. Convergent validity test uses 2 parameters, namely outer loading (OL) and average variance extracted (AVE). The OL value of a variable item is greater than 0.7 and the AVE value is greater than 0.5 , so seen from the convergent validity, this item is valid (Hair et al., 2014; Saldanha et al., 2018, 2019). Figure 2 shows that the OL value of all items in this study is greater than 0.60 , and this value has no effect on content validity. Table 1 also shows that the AVE value of all items in this study is greater than 0.50 . So, all items of each variable are valid as seen from the convergent validity to test the relationship between variables (inner model measurement).

Table 1. Reliability (Cronbach's alpha and composite reliability) and convergent validity (AVE)

\begin{tabular}{|c|c|c|c|}
\hline Item & CA & CR & A VE \\
\hline CS & 0.660 & 0.815 & 0.597 \\
\hline FQ & 0.828 & 0.874 & 0.538 \\
\hline IR & 0.678 & 0.819 & 0.603 \\
\hline SQ & 0.711 & 0.823 & 0.542 \\
\hline
\end{tabular}

Seen from discriminant validity, the AVE value of the indicator for the indicator (CS1 for CS1) is greater for the other indicators. Table 2. shows the AVE indicator value for the indicator is greater Hair et.al (2017). Therefore all indicators are valid using Fornell - Larscker Criteria.

Table 2. Fornell-Larcker Criteria for DiscriminantValidity

\begin{tabular}{|c|c|c|c|c|}
\hline Item & CS & FQ & IR & SQ \\
\hline CS & 0.772 & & & \\
\hline FQ & 0.566 & 0.733 & & \\
\hline IR & 0.501 & 0.408 & 0.777 & \\
\hline SQ & 0.617 & 0.384 & 0.414 & 0.736 \\
\hline
\end{tabular}


Discriminant validity is also measured by the heterotraitmonotrait (HTMT) parameter. Table 3. shows that all HTMT values are smaller than 0.85 . So, all indicators are valid using HTMT (Henseler et al. 2015).

Seen from the validity test, the results show that convergent validity and discrinant validity, all indicators are valid to test the relationship between variables (inner model measurement).

\subsection{Hypothesis Test}

In this study, the first hypothesis tested is the relationship or influence of service quality (SQ) with customer satisfaction (CS). The Smart-PLS 3.0 test results show that the $\mathrm{T}$ value (5.744) is greater than 1.96 and the $P$ value $(0.000)$ is smaller than 0.05 . This shows that service quality has a positive and significant effect on customer satisfaction. Therefore, H1 is supported.

In this study, the second hypothesis tested is the relationship or influence of food quality (FQ) on consumer satisfaction (CS). From the Smart-PLS 3.0 test results, it shows that the $T$ value (4.087) is greater than 1.96 and the $P$ value $(0.000)$ is smaller than 0.05 . This means that food quality has a positive and significant effect on consumer satisfaction. So, H2 is supported.

\subsection{Hypothesis Test}

In this study, the first hypothesis tested is the relationship or influence of service quality (SQ) with customer satisfaction (CS). The Smart-PLS 3.0 test results show that the $\mathrm{T}$ value (5.744) is greater than 1.96 and the $\mathrm{P}$ value $(0.000)$ is smaller than 0.05 . This shows that service quality has a positive and significant effect on customer satisfaction. Therefore, H1 is supported.

In this study, the second hypothesis tested is the relationship or influence of food quality (FQ) on consumer satisfaction (CS). From the Smart-PLS 3.0 test results, it shows that the $\mathrm{T}$ value (4.087) is greater than 1.96 and the $\mathrm{P}$ value $(0.000)$ is smaller than 0.05 . This means that food quality has a positive and significant effect on consumer satisfaction. So, H2 is supported.
In this study, the third hypothesis tested is the relationship or influence of food quality (FQ) on restaurant image (RI). From the Smart-PLS 3.0 test results, it shows that the $T$ value (2.367) is greater than 1.96 and the $P$ value (0.018) is smaller than 0.05 . This means that food quality has a positive and significant effect on restaurant image. So, H3 is supported.

In this study, the forth hypothesis tested is the relationship or influence of fservice quality (FQ) on restaurant image (RI). From the Smart-PLS 3.0 test results, it shows that the $\mathrm{T}$ value (2.215) is greater than 1.96 and the $\mathrm{P}$ value (0.027) is smaller than 0.05 . This means that service quality has a positive and significant effect on restaurant image. So, H3 is supported.

In this study, the fifth hypothesis tested is the relationship or influence of restaurant image (IR) on consumer satisfaction (CS). From the Smart-PLS 3.0 test results, it shows that the $\mathrm{T}$ value (2.116) is greater than 1.96 and the $\mathrm{P}$ value is smaller $(0.035)$ less than 0.05 . This means that restaurant image has a positive and significant effect on consumer satisfaction. So, H3 is supported.

In this study, the sixth hypothesis tested is the mediation effect of restaurant image (IR) on the relationship between food quality (FQ) and consumer satisfaction (CS). From the Smart-PLS 3.0 test results, it shows that the T value (1.498) is greater than 1.96 and the $P$ value is smaller $(0.135)$ greater than 0.05 . This means that restaurant image has not a positive and significant effect on the relationship between food quality and consumer satisfaction. So, H6 is not supported.

In this study, the seventh hypothesis tested is the mediation effect of restaurant image (IR) on the relationship between service quality (FQ) and consumer satisfaction (CS). From the Smart-PLS 3.0 test results, it shows that the $T$ value (1.578) is greater than 1.96 and the $P$ value is smaller (0.115) greater than 0.05 . This means that restaurant image has not a positive and significant effect on the relationship between food quality and consumer satisfaction. So, H7 is not supported. 
Table 4. Path Coefficient for Hypothesis Test

\begin{tabular}{lcccccc}
\hline & $\begin{array}{c}\text { Original } \\
\text { Sample (O) }\end{array}$ & $\begin{array}{c}\text { Sample } \\
\text { Mean (M) }\end{array}$ & $\begin{array}{c}\text { Standard } \\
\text { Deviation } \\
\text { (STDEV) }\end{array}$ & $\begin{array}{c}\text { T Statistics } \\
(|\mathrm{O} / \mathrm{STDEV}|)\end{array}$ & P Values & Note \\
\hline FQ -> CS & 0.328 & 0.340 & 0.080 & 4.087 & 0.000 & Significant \\
FQ -> RI & 0.293 & 0.303 & 0.124 & 2.367 & 0.018 & Significant \\
RI -> CS & 0.198 & 0.176 & 0.094 & 2.116 & 0.035 & Significant \\
SQ -> CS & 0.408 & 0.414 & 0.071 & 5.744 & 0.000 & Significant \\
SQ -> RI & 0.302 & 0.303 & 0.136 & 2.215 & 0.027 & Significant \\
FQ -> IR -> CS & 0.058 & 0.054 & 0.039 & 1.498 & 0.135 & Not significant \\
\hline
\end{tabular}

\subsection{Discussion}

The first objective of this study was to determine the effect of food quality (FQ) on consumer satisfaction (CS). The results showed that food qaulitas had a positive and significant effect on consumer satisfaction. This shows that the dimensions of food quality (freshness, food presentation, food maturity and food variety) have a positive and significant effect on consumer satisfaction. When a restaurant provides food well, it will positively affect customer satisfaction. The factor that most determines customer satisfaction is significance, which means that the staff will give capability and trust to consumers and responsibility means that a good desire to provide fast service. Some aspects are needed to see about production activities with good quality. According to Tjiptono (2002) that quality as a dynamic condition that has a relationship with production, service, people, processes and places in accordance with standards. Quality comes from the availability of equipment, ingredients, and processing time to get good and quality food results to ensure customer satisfaction when eating at a restaurant. Therefore, the results show that consumers are satisfied with the food provided by the restaurant. This study is confirmed by previous empirical research which proves that food quality has a positive and significant effect on consumer satisfaction (Ryu et al., 2012; Yamit, 2010; Kotler \& Armstrong, 2012; Margareta \& Edwin, 2012; Namkung \& Jang, 2007; Ryu \& Han, 2010).

The second objective of this study is to examine the effect of service quality (SQ) on customer satisfaction (CS). The results showed that service quality has a positive and significant effect on customer satisfaction. This means that 5 indicators of service quality are: tangible, as seen from the physical facilities, staff, and equipment provided to consumers; reliability means showing ability and trust in consumers; Responsiveness relates to the good desire to serve quickly; Assurance related to knowledge about good behavior, respect when serving consumers; Empathy, which relates to love and individual attention to consumers (Kotler, 2001; Zeithaml, 2000). When the quality of service is good, it has a positive impact on customer satisfaction.
Some previous empirical research has found that service quality has a positive effect on customer satisfaction (Chnadra et al., 2019; Asnawi et al., 2019; Khoo, Ha, \& McGregor, 2017; Rahman, hasan, Osaman-Gani, Abdel Fattah, \& Anwar, 2017; Subrahmanyam, 2017). But there are also other studies that show the results that service quality has no effect on customer satisfaction (Meesala \& Paul, 2018). These differences might be appeared due to different size, types and environment of the hotels.

The third objective of this study was to examine the effect of food quality (FQ) on restaurant image (RI). The results showed that food quality had a positive and significant effect on restaurant image. This means that the indicator of food quality is seen from food color; how to combine colors from vegetables and meat; food spices such as salads, soups, food portions, food taste must be in accordance with consumer desires; Presentation, food should be clean, nice and attractive; Aromatic, the food provided must be fresh, fragrant and increase appetite (Gaman et, al., 1996; Jones, 2000). With several indicators that make respondents' perceptions provide great value. Automatically with a large value will have a positive and significant effect on the restaurant image. From emperic research before confirming that food quality has a positive and significant effect on restaurant image (Vijver, 2007; Kotler and Armstrong, 2020)

The fourth objective of the study was to examine the effect of service quality (SQ) on restaurant image (RI). The results showed that service quality has a positive and significant effect on restaurant image. With existing indicators, make consumers give their feelings by giving great value. This means that restaurant staff provide services according to customer desires. When consumers need information about the menu, restaurant staff must have the intention to help them so that they feel comfortable when meeting restaurant staff, and sometimes restaurant staff also need to use modern equipment to serve consumers.

Restaurant image as a result of comparison of consumers to product attributes of an industry. These attributes come from food production, price, service, physical facilities and 
the environment. Unfortunately, with this idea, consumers will provide a subjective perception of the restaurant facilities and existing activities. There will be different perceptions between the respondents but the majority of respondents agree with the attributes of the restaurant. Prior empirical research shows that service quality has a positive and significant effect on restaurant image (Namkung \& Jang, 2008; Ryu et al. 2008;460; Ryu et al.(2012).

The fifth objective of this study is to examine the effect of restaurant image on customer satisfaction. The results showed that restaurant image had a positive and significant effect on customer satisfaction. This means that many respondents agree with the product attributes at the restaurant. Consumers feel that this restaurant is good and sophisticated because the environment is good and attractive to them, and provides good food compared to the existing prices.

Satisfaction comes from individual feelings about the products used and these products give satisfaction to consumers. The results show that restaurant waiters serve consumers according to their expectations. Prior empirical research also proved that customer satisfaction comes from feeling happy, not happy with work results (Kotler 2014:150; Barnes, 2003:64; Ryu et al., 2008;460).

The sixth research objective was to examine the effect of restaurant image mediation on the relationship between food quality and consumer satisfaction. The results showed that there was no mediating effect of restaurant image on the relationship between food quality and customer satisfaction. This means that the quality of the food is good and delicious, has nutrition, provides a lot of menus, the food is fresh, fragrant, interesting, but does not have a significant effect on the restaurant's image. From this it can be seen that the quality of food is not an option for consumers but because they feel hungry and do not care about the facilities and architecture in the restaurant.

The results of this study are different from previous empirical research which shows that food quality has a positive and significant effect on restaurant image and customer satisfaction (Ryu et al., 2012; Kotler \& keller 2009:406; Margareta \& Edwin, 2012).

The sixth research objective was to examine the effect of restaurant image mediation on the relationship between service quality and consumer satisfaction. The results showed that there was no mediating effect of restaurant image on the relationship between service quality and customer satisfaction. Thus, the service quality of restaurant staff is not in accordance with the provision of food in accordance with consumer desires, good and fast service, helping consumers feel comfortable, using modern equipment to serve even though there is no positive response to restaurant image and customer satisfaction. This shows that service quality is not an important area for consumers, what matters is that the staff must carry out their duties, but consumers do not feel that this service is of quality or not.
The results of this study differ from the results of previous studies that service quality has a positive and significant effect on restaurant image and customer satisfaction (Kotler; 2000; Ruslan, 2006 : 281; Sharabi \& Davidow, 2010; Gummesson, 1998; Ryu \& Han, 2010; Kotler \& Keller, 2009:406; Kotler \& Keller, 2012; Meesala \& Paul, 2018) because different culture, economic background and environment. In lower economic condition, customers prefere to choose product price and quality than restaurant image. In addition, many previous empirical studies were carrying out in wstern countries which quality and image are determinant factors for customers to choose one restaurant.

\section{Conclusions and Implications}

Food quality, service quality and restaurant image are the most important pillars for the hospitality industry. In-depth research can help the business industry, especially the hotel industry area. Many empirical research shows that testing between variables is inconsistent, some are significant and some are not significant.

The results of this study reinforce the inconsistencies of previous studies. Thus food quality has a positive and significant effect on customer satisfaction but not significant on restaurant image. This shows that consumers know to compare facilities and interior designs in restaurants and decide that the existing facilities and designs are not what they want and make consumers dissatisfied.

The results of this study also indicate that there is no mediating effect of restaurant image on the relationship between food quality, service quality and customer satisfaction. This reinforces the results of previous studies that people can be satisfied with food quality, service quality but not satisfied restaurant image.

\section{Limitation and Future Research}

This study is to analyze the mediating effect of restaurant image on the relationship between food quality, service quality and consumer satisfaction. To analyze these variables, the researcher used a questionnaire to get respondents from the respondent.

1) For subsequent research, in-depth interviews and direct observation from small restaurants to large restaurants in Dili can be used to compare the existing variables.

2) This research is an exploratory study to see about food quality, service quality, customer satisfaction, restaurant image in the context of hospitality, especially restaurants.

3) This study only looks at the work of restaurant staff in ensuring customer satisfaction but is not associated with other activities in the restaurant.

This research has only been conducted once and further research is needed to generalize the relationship between variables and the research model better. 


\section{References}

WidiP., C.A., Utomo, W.H., \& Wijaya, A.F. (2013). Customer Satisfaction Analysis to Health Service by Servqual 5 Dimension Method and Customer Satisfaction Index. International Journal of Computer Applications, 70(12), 17-21

Abdullaeva, M. (2020). Impact of Customer Satisfaction on Customer Loyalty in Upscale Ethnic Restaurants. Theoretical \& Applied Science, 86(06).

Abror, A., Patrisia, D., Engriani, Y., Evanita, S., Yasri, Y., \& Dastgir, S. (2019). Service quality, religiosity, customer satisfaction, customer engagement and Islamic bank's customer loyalty. Journal of Islamic Marketing, Vol. 11(6)1691-1705.

Ali, M., Puah, C. H., Ayob, N., \& Raza, S. A. (2019). Factors influencing tourist's satisfaction, loyalty and word of mouth in selection of local foods in Pakistan. British Food Journal, 122(6), 2021-2043.

Asnawi, N., Sukoco, B. M., \& Fanani, M. A. (2019). The role of service quality within Indonesian customers satisfaction and loyalty and its impact on Islamic banks. Journal of Islamic Marketing. DOI 10.1108/JIMA-03-2017-0033.

Boonlertvanich, K. (2019). Service quality, satisfaction, trust, and loyalty: the moderating role of main-bank and wealth status. International Journal of Bank Marketing, 37(1), 278-302.

Carranza, R., Díaz, E., \& Martín-Consuegra, D. (2018). The influence of quality on satisfaction and customer loyalty with an importance-performance map analysis: Exploring the mediating role of trust. Journal of Hospitality and Tourism Technology, 9(3), 380-396.

Chandra, T., Hafni, L., Chandra, S., Purwati, A. A., \& Chandra, J. (2019). The influence of service quality, university image on student satisfaction and student loyalty. Benchmarking: An International Journal, https://doi.org/10.1108/BIJ-07-2018-0212

Erkmen, E., \& Hancer, M. (2019). Building brand relationship for restaurants: An examination of other customers, brand image, trust, and restaurant attributes. International Journal of Contemporary Hospitality Management, 31(3), 1469-1487.

Evert Gummesson. (1998). Productivity, quality and relationship marketing in service operations. International Journal of Contemporary Hospitality Management, Vol. 10 (1) 4-15.

F. Hair Jr, J., Sarstedt, M., Hopkins, L., \& G. Kuppelwieser, V. (2014). Partial least squares structural equation modeling (PLSSEM). European Business Review, 26(2), 106-121.

Firescu, V. (2015). Comprehensive Income, a New Dimension in Performance Measurement and Reporting. Procedia Economics and Finance, 20(15), 218-223.

FrankT., R. (2017). Strategic Management (Third Edit). New York: Mc Graw Hill Education.
Hair, J., Hollingsworth, C. L., Randolph, A. B., \& Chong, A. Y. L. (2017). An updated and expanded assessment of PLS-SEM in information systems research. Industrial Management \& Data Systems, 117(3), 442-458.

Hapsari, R., Clemes, M. D., \& Dean, D. (2017). The impact of service quality, customer engagement and selected marketing constructs on airline passenger loyalty. International Journal of Quality and Service Sciences, 9(1), 21-40.

Henseler, J., Ringle, C. M., \& Sarstedt, M. (2015). A new criterion for assessing discriminant validity in variance-based structural equation modeling. Journal of the Academy of Marketing Science, $43(1), 115-135$

Ing, P. G., Zheng Lin, N., Xu, M., \& Thurasamy, R. (2019). Customer loyalty in Sabah full service restaurant. Asia Pacific Journal of Marketing and Logistics, Vol. 32, pp1407- 1429.

Iordanova, E., \& Stylidis, D. (2019). The impact of visitors' experience intensity on in-situ destination image formation. Tourism Review, 74(4), 841-860.

Jari, J., Jouni, J., \& Grant, D. B. (2010). Service quality and its relation to satisfaction and loyalty in logistics outsourcing relationships. Managing Service Quality: An International Journal, 20(6), 496-510.

Jeong, E. H., \& Jang, S. C. (Shawn). (2018). The affective psychological process of self-image congruity and its influences on dining experience. International Journal of Contemporary Hospitality Management, 22, 433-444.

Karen, B., Fjord, T.A., Grunert, K.G. (2002). Consumers ' Food Choice and Quality Perception. Perception, 1-60. https://doi.org/ISSN 09072101

Khattab, F. (2018). Developing a Service Quality Model for Private Higher Education Institutions in Lebanon. Journalof Management and Marketing Review, 3(1), 24-33.

Khudri, M. M., \& Sultana, S. (2015). Determinants of service quality and impact of service quality and consumer characteristics on channel selection. British Food Journal, 117(8), 2078-200

Kotler, P., Wong, V., Saunders, J., Armstrong, G. (1999). Principples of Marketing (4th Edition). London:Prentice Hall.

Mannan, M., Chowdhury, N., Sarker, P., \& Amir, R. (2019). Modeling customer satisfaction and revisit intention in Bangladeshi dining restaurants. Journal of Modelling in Management, 14(4), 922-947.

Meesala, A., \& Paul, J. (2018). Service quality, consumer satisfaction and loyalty in hospitals: Thinking for the future. Journal of Retailing and Consumer Services, 40, 261-269.

Mishra, J. K. (2007). Constituent Dimensions of Customer Satisfaction: A Study of Nationalised and Private Banks. Revista Tinerilor Economiúti, (January), 40-47. 
Mohajerani, P., \& Miremadi, A. (2012). Customer Satisfaction Modeling in Hotel Industry: A Case Study of Kish Island in Iran. International Journal of Marketing Studies, 4(3), 134-152.

Namkung, Y., \& Jang, S. C. (2008). Are highly satisfied restaurant customers really different? A quality perception perspective. International Journal of Contemporary Hospitality Management, 20(2), 142-155.

Nawi, N. B. C., Al Mamun, A., Nasir, N. A. M., Abdullah, A., \& Mustapha, W. N. W. (2019). Brand image and consumer satisfaction towards Islamic travel packages. Asia Pacific Journal of Innovation and Entrepreneurship, 13(2), 188-202.

Neupane, R., \& Devkota, M. (2017). Evaluation of the Impacts of Service Quality Dimensions on Patient/Customer Satisfaction: A Study of Private Hospitals in Nepal. International Journal of Social Sciences and Management, 4(3),

Pakurár, M., Haddad, H., Nagy, J., Popp, J., \& Oláh, J. (2019). The service quality dimensions that affect customer satisfaction in the Jordanian banking sector. Sustainability (Switzerland), 11(4), 1-24.

Panthi, A., \& Karki, D. (2018). How Food Quality , Price , Ambiance and Service Quality Effects Customer Satisfaction : A study on Nepalese Restaurants in Finland, 1-38.

Paul, J., Mittal, A., \& Srivastav, G. (2016). Impact of service quality on customer satisfaction in private and public sector banks. International Journal of Bank Marketing, 34(5), 606-622.

Pedraja Iglesias, M., \& Jesus Yagüe Guillén, M. (2004). Perceived quality and price: Their impact on the satisfaction of restaurant customers. International Journal of Contemporary Hospitality Management, 16(6), 373-379.

Pender, L., \& Sharpley, R. (2005). Management of Tourism - Tour operations management. (S. R. and pender Lesley, Ed.), Tourism (First). SAGE PUBLICATIONS.

Kotler, P. (2003). Marketing insights from A toZ. New Jersey: John Wiley \& Sons, Inc.

Pooya, A., Abed Khorasani, M., \& Gholamian Ghouzhdi, S. (2020). Investigating the effect of perceived quality of self-service banking on customer satisfaction. International Journal of Islamic and Middle Eastern Finance and Management, 13(2), 263-280.

Rahimi, R., Okumus, F., Jayashree, S., Bihamta, H., \& Rezaei, S. (2017). Dual pillars of hotel restaurant food quality satisfaction and brand loyalty. British Food Journal.

Richardson, S., Lefrid, M., Jahani, S., Munyon, M. D., \& Rasoolimanesh, S. M. (2019). Effect of dining experience on future intention in quick service restaurants. British Food Journal, 121(11), 2620-2636.

Ryu, K., Lee, H. R., \& Kim, W. G. (2012). The influence of the quality of the physical environment, food, and service on restaurant image, customer perceived value, customer satisfaction, and behavioral intentions. International Journal of Contemporary
Hospitality Management, Vol. 24 No. 2, pp. 200-223

Sabir, R. I., Irfan, M., Akhtar, N., Pervez, M. A., and Rehman, A. U. (2014). Customer Satisfaction in the Restaurant Industry; Examining the Model in Local Industry Perspective. Journal of Asian Business Strategy, 4(1), 18-31. Retrieved from

Sadílek, T. (2018). Perception of food quality by Czech consumers - Literature review. Proceedings of the 31st International Business Information Management Association Conference, IBIMA 2018: Innovation Management and Education Excellence through Vision 2020, XXII(1), 6183-6191.

Sadílek, T. (2019). Consumer preferences regarding food quality labels: the case of Czechia. British Food Journal, 121(10), 25082523.

Saldanha, E. D. S., Rahyuda, I. K., Yasa, N. N. K., \& Sukaatmadja, I. P. G. (2019). Persaingan Industri, Strategi Bisnis, dan Kinerja Industri. Denpasar: Udayana University Press.

Sharabi, M., \& Davidow, M. (2010). Service quality implementation: problems and solutions. International Journal of Quality and Service Sciences, 2(2),

Souki, G. Q., Antonialli, L. M., Barbosa, Á. A. da S., \& Oliveira, A. S. (2019). Impacts of the perceived quality by consumers' of à la carte restaurants on their attitudes and behavioural intentions. Asia Pacific Journal of Marketing and Logistics, 32(2), 301-321.

Sugiyono. (2014). Metode Penelitian Kuantitatif, Kualitatif dan R\&D.

Tomczak, T., Reinecke, S., \& Kuss, A. (2018). Strategic marketing: Market-oriented corporate and business unit planning. Strategic Marketing: Market-Oriented Corporate and Business Unit Planning.

Van Rijswijk, W., \& Frewer, L. J. (2008). Consumer perceptions of food quality and safety and their relation to traceability. British Food Journal,

Vijver, L. van de. (2007). Measuring food quality: concepts, methods and challenges-Proceedings seminar February 2007, (February), 1-33. Retrieved

Wu, H. C., Cheng, C. C., \& Ai, C. H. (2019). What drives green experiential loyalty towards green restaurants? Tourism Review, (2018), 1-20.

Zameer, H., Tara, A., Kausar, U., \& Mohsin, A. (2015). Impact of service quality, corporate image and customer satisfaction towards customers' perceived value in the banking sector in Pakistan. Marketing Intelligence and Planning, 


\section{Appendix A : Research Instrument}

\section{Food Quality (FQ)}

\begin{tabular}{|c|c|c|}
\hline No. & Questionnaire & Likert Scale \\
\hline FQ1 & $\begin{array}{l}\text { The food in the restaurant has good } \\
\text { tasteful }\end{array}$ & $\begin{array}{llll}1 & 2 & 3 & 4\end{array}$ \\
\hline FQ2 & $\begin{array}{l}\text { The food in this restaurant has } \\
\text { good nutrition }\end{array}$ & \\
\hline FQ3 & $\begin{array}{l}\text { This restaurant provides a lot of } \\
\text { menus }\end{array}$ & \\
\hline FQ4 & This restaurant provides fresh food & \\
\hline FQ5 & This restaurant has fragrant food & \\
\hline FQ6 & $\begin{array}{l}\text { The food in this restaurant attracts } \\
\text { people's attention. }\end{array}$ & \\
\hline \multicolumn{3}{|c|}{ 2. Service Quality (SQ) } \\
\hline No. & Questionnaire & Likert Scale \\
\hline SQ1 & $\begin{array}{l}\text { This restaurant staff gave me } \\
\text { food according to what I } \\
\text { wanted. }\end{array}$ & $\begin{array}{lllll}1 & 2 & 3 & 4 & 5\end{array}$ \\
\hline SQ2 & $\begin{array}{l}\text { The staff of this restaurant } \\
\text { serve well and quickly }\end{array}$ & \\
\hline SQ3 & $\begin{array}{l}\text { This restaurant staff is always } \\
\text { helping clients }\end{array}$ & \\
\hline SQ4 & $\begin{array}{l}\text { This restaurant staff makes me } \\
\text { always comfortable when I } \\
\text { meet }\end{array}$ & \\
\hline SQ5 & $\begin{array}{l}\text { This restaurant staff uses } \\
\text { modern equipment to serve } \\
\text { clients }\end{array}$ & \\
\hline
\end{tabular}

3. Restaurant Image (RI)

\begin{tabular}{|c|c|c|}
\hline No. & Questionnaire & Likert Scale \\
\hline IM1 & $\begin{array}{l}\text { This Restaurant is good } \\
\text { (sophisticated) }\end{array}$ & $\begin{array}{lllll}1 & 2 & 3 & 4 & 5\end{array}$ \\
\hline IM2 & $\begin{array}{l}\text { This restaurant has a nice and } \\
\text { attractive environment }\end{array}$ & \\
\hline IM3 & $\begin{array}{l}\text { This restaurant has good } \\
\text { tasteful food at fair prices }\end{array}$ & \\
\hline \multicolumn{3}{|c|}{ 4. Customer Satisfaction (CS) } \\
\hline No. & Questionnaire & Likert Scala \\
\hline CS1 & $\begin{array}{l}\text { I am satisfied with all } \\
\text { experiences with this restaurant }\end{array}$ & $\begin{array}{lllll}1 & 2 & 3 & 4 & 5\end{array}$ \\
\hline CS2 & $\begin{array}{l}\text { Overall, this restaurant made } \\
\text { me feel good }\end{array}$ & \\
\hline CS3 & $\begin{array}{l}\text { I am happy to eat at this } \\
\text { restaurant }\end{array}$ & \\
\hline
\end{tabular}

